\title{
Intensity Appearance in Styles
}

\author{
Khayala Mursaliyeva Mugamat \\ Sumgayit State University, Republic of Azerbaijan, (Ph.d student)
}

\begin{abstract}
Different expressive emotional categories are paid attention in linguistics recently and this serves to the attitude expressing speech method addressed to real reality factors. The concept of intensity isn't new conception in linguistics. This conception is often met in the questions connect with expressive style, emotional texts and in research work connects with speech and evaluation features.
\end{abstract}

Keywords: intensive, intensiveness, functional styles, intensity degree in literal styles, intensity degree in speaking style

\section{Introduction}

Intensity is one of the categories of functional-semantic categories. The aim of our investigation is to study the use of intensity in Azerbaijan language's functional styles and to define the intensity degree in these styles.

Firstly, look through the explanation of intensity in linguistics. The word "Intensive" is translated as strained and efficiency. The meaning of "Intensity" is strainess, efficienciness. Derivative term "To intensive" is used in different fields of life: f.ex. intensifying economy (to do smth effecience) and etc. [10, p.575] The meaning of "Intensive" (intensio) is translated as strained, strong in Explanatory dictionary in Azerbaijan language. [9, p.559]

In "Explanatory linguistics terms of Azerbaijan language dictionary" in the dictionary article is noted that "intensive" is the word form strenghtening the meaning than the root. F.ex. poet makes intensity with using "(to be riddled - şanəşanə olmaq" instead of "to have a lot of holes (şan-şan)". (Băgrım olub şanə-şano, durnalar!- My heart riddled into piceses, cranes!) [12, p.236]

Görmazə-bilməzə - not knowning (instead of just not knower-görməz-bilməz): gur-gur guruldamaq - roaring soundly (instead of just roar-guruldamaq): azim-əzim azmək - to smash hardly (instead of "just smash - azmok):

The meaning of "Intensive" term is given as following in this dictionary: strong or weak side of sounds articulation (especial vowels); strong or weak degree of respiration (breathing); Sound intensity is the power of sound. [3, p.119, 370] "Changing tone" makes opportunity to intensity. According to G.Mustafayeva it is possible to use the same word in order form by changing different tones during conversation for different purposes. F.ex. Use the words read-oxu, go-get, come-galmok in order form, then in request, permission form and then as instigating units and it's possible to understand. [8, p.344]

In the result of investigation it's clear that the conception intensity differs from other categories of language with its thought emphasizing, strengthening, and enlarging characters. Intensity existing in all levels of language (phonetics, lexica, onomastic, morphology, syntactic and etc.)
Intensive takes part in as lexical units in the system of lexica and Grammatik, "choosing language units in the expedient connects with the direction of aim and character and even is appointed by it". [8, p.5] Using degree of intensity is different in Azerbaijan language. Nowadays efficient functional styles are as followings:
1) Literary speaking style
2) Artistic style
3) Scientific style
4) Official style
5) Publicist style
6) Epistolary style

Literary speaking style divides into two groups: official speaking style and unofficial speaking style. In official literary speaking style is spoken like book language, there is no any literary and rule norms unfollowing process and here is not used any factors and intensives which is created intensity. Unofficial speaking style is called spoken languge with other term. During using the language units in spoken style is made a way for freedom, in the result it'spossible to express the thought intensivly. Speaking style is the most popular among the functionalı styles. A.M.Gurbanov said: "Exclamation amd modal words from indefinite parts of speech is often addressed in literary spoken style". These types of words can increase emotional expressive quality of the speech. [6, p.186]

As we know, intensity occurs when quality is an action and development. Elliptic form of unfinished and brief sentences in literary spoken language is caused to express thought vividly.

F.ex: Gözün aydın olsun! - Be happy! Homişa işdə (olasan)! - Be always at work. Homişa toyda (olasan)! - Be always in wedding! Homişa evindo-eşiyindo (olasan) - Be always in your home! Har vaxtınız xeyir olsun! - Good day! Sabahınız xeyir (olsun)! - Good morning! Gecəniz xeyro (qalsin) Good night!...

In the literary style one of the functional styles intensity shows itself more vividly. Thus, the power of expressing means of intensity depends on personality of literary work author, personal quality of author, from world vision, from speech temperament, from intellectual emotion and sense degree. Surprising suitable time, method stands in the base of intensity. Personal, liar, author speech and its subject are

Volume 5 Issue 7, July 2016 


\section{International Journal of Science and Research (IJSR) \\ ISSN (Online): 2319-7064}

Index Copernicus Value (2013): 6.14 | Impact Factor (2015): 6.391

stand in the base of intensity in literary text. Artistry, brevity and laconic are the main features of literary style. There are two types of literary style: poetry language, prose language. Poetry language has a great role in expressing thought distinctly.

Intensity feature show itself in repetition of verbal predicate but in more time in intensification of thought and motion durability process. By this purpose, simple and complex verbal predicate which derived from the same root may to repeat.

Give me way, I picked up flowers for my lover!

Search, search, search and then I find you [5, p.75]

$* * *$

Disintegrate slavery land,

Stand up, stand up poor world! [5.p.75]

Yol ver mənə, gül dərmişəm, sevdiyimçin aparım! Arar, arar, arar, arar axır səni taparım $* * *$

Silkin, uçsun kölaliyin torpa $\breve{g}$

Qalx, qalx, qalx,qalx düşkün dünya!

The repetition words search and stand up are caused to express thought distinctly. We dealt with the role of main and auxiliary parts of speech in intensity in another scientific article. In language all parts of speech may take part in intensity, the role of these parts of speech are different. Adjective, verb, modal words, exclamations have a great role in intensity. It's possible to meet the particles which occur intensity:

Such: Strangeness is such a toture that is not born. Qariblik ela bir dord ki, çəkilmaz. [11, p.219]

As if: Something missing... Nasa çatmır...

Something missing...

Vauuuu,

Even the day something missing. Lap günda da nasa çatmır.

$[11, p .171]$

Ha: I'm speaking with you: ha, mon səninlo danışıram:

You're writing that: Dont miss, ha... Yazırsan ki: Darıxma, ha... [11, p.270]

Another: Another crime, another error! Daha bir cinayat, daha bir xata! [11, p.187]

According to the M.Adilov intensity belongs to live speaking language and oral language mainly. He emphasized that intensity connects with moral-sensetive features of humans. That's why intensity is met in literary style specially in people language. [2, p.24-25]

Intensive form of adjective is met in literary style in the language of writer and images. For example:

I saw, Farhad droped head dawn, turned into dark red and he was in such a mood he would bleed if you flick him. [4, p.204] - Gördüm Forhad başını salıb aşă̆l, qıipqırmızı qızarıb va ela bir haldadır ki, çırtma vursan qanı damar.

Dark yellow fried egg, dark green onion, dark red radish. What a better gift there is? [4, p.204] - Sapsarl qayqanaq, yamyaşıl soğan, qıpqırmızı turp. Bundan gözal hansı nemat var?
Evacuation - icy, crowded wagons, winds hit endless waitings... [4, p.326] - Evakuasiya - bumbuz, basirlq vaqonlar, külaklarin döydüyü sonu görünməyən gözlamələr...

Blue sea, dark blue sea, and snow white ship. [4, p.366] Göy dəniz, gömgöy dəniz, bir do ăgappaq gəmi.

Intensity is formed by ripitition of direct adress in literary style, here the meaning of challange privails.

When elavator passed the thirdfloor, director of today's dub Aga Mehdi seeing the Feyzullah on stairs:

- Kabrlinski, Kabrlinski - he called [4, p.389]

Lift 3-cü martabadan keçənda bugünkü dublyajin rejissoru Ăga Mehdi pillakandan Feyzullanı görüb:

-Kabrlinski, Kabrlinski-deya çağırdı

When epigraphy comes before the text they consider with the same text content, and author increase the influence of expressing thought by these. [6, p.190] Scientific style is one of scientific-functional of literary style, used in all scientific activity fields. Scientific style is characterized with its accurate, logicality and compactness. The factors of intensity isn't met in this style. Person who used to speak and write in scientific style mustn't address to other styles. Speaker reporting scientific problems, if it's necessary (in order to attract attention, increase the influence of thought) can use other means belong to literary language. [1, p.196]

According to A.Gurbanov emotional expressive colors isn't use in scientific style. [6, p.192]. Publisistic style is characterized with its simpility, compactness and sharpness. Unfinished sentences, unfinished rithoric questions, ripititions are caused to express thought distinctly in this style. F.ex:

Snow white flower is this snow gift
Resembling covers soil torture $[13, \mathrm{p} .6]$

Bəmbəyaz çiçəkdir bu qar töhfəsi

Torpağın dərdini oxşayır örtür

Vauu! Nobody see, not see! One white car was in dark red blood, as if the car was flowed a bucket of blood from top, in order to be red. [14, p.32]

Boyyyy! Heç kim görmasin, görməsin! Bir ă̆ maşın bütün qıpqırmızı qanıydı, ela bil maçının baçından vedraynən bir qan axıtmışdın ki, qurmızılı̆̆a çıxsın.

Standart forms are used in offisial style, that's why there is no edge thought and comments here. Different types of documents are prepared in offisial style and the language of any problems must be clear, explained shortly, not to use additional words, repetitions and artistic means.

Epistolary style was formed on base of appearing different types of letters. This style is used in family-domestic, friendship letters, official letters and in open letters. Here we can meet distinctly thought, inflating and enlarging meaning. For the sample let's look through Mirza Calil's letter to Sydgi in 1911.

\section{Volume 5 Issue 7, July 2016} www.ijsr.net 


\section{International Journal of Science and Research (IJSR) \\ ISSN (Online): 2319-7064 \\ Index Copernicus Value (2013): 6.14 | Impact Factor (2015): 6.391}

"Today I telegram to Samadov's to give you 50 manat. Journal hasn't been brought, I didn't know. Take care off house and children. For Muzaffar's not walking so much, strive. Take Munavar's dress and do every needed things. Write anything you have. Send the newspapers" [7, p.836] $* * *$

"Bugün Samadovlara tel vurdum, sanə 50manat versin. Jurnal galmir, bilmiram niyə? Evdan va uşaqlardan mugayyat ol. Müzaffar çox gazməsin va say elosin. Münavvarin paltarını al va na lazım olsa, birabir ela. Har no sözün olsa, yaz. Qazetlari göndar”

Means expressing intensity are strinked mostly in speaking process. M.Adilov answered to the question "what is the language elements that denote intensity?" "As our thought, elements which haven't phonetics, lexsic and grammatic concepts, namely served to intensity. In this case, intensity connects with stylistic closely" [2, p.22]

It's clear that, double possesive suffixes, quantaty category, imperative mood, intensive form of adjective, superlative degree of adverb and etc can act as an factors of intensity. These types differ with quantity difference and characterized with the colours of literary style.

Repeitition of direct adresses in poetry branch of literary style makes possible to express intensive thought. F.ex:

Bing a giour, gets a cross, ey Babayi-mir!

Don't close your eyes, open, ey Babayi-mir!

Don't stop, things look blue, run away, ey Babayi-mir! [5, p. 82]

Kafir olub, salmisan xaç, a Babayi-mir! Yumma, doxi gözlorin aç, a Babayi-mir! Durma, şuluqdur işin, qaç, a Babayi-mir!

Beside this, repetition used in poetry branch of literary style creates intensity. F.ex:

I smash your head, not looking consciense

Penitence... penitence, again I came to penitence

$$
[5, p .91]
$$

Әzaram baş-gözünü, baxmaram heç vicdanə Tövbə...tövba..., yena tövba galiram imana

\section{Result}

In the result of researching its obvious that, intensity forming language means isnt used because of following accurate norm in official style which is one of function style. Language means forming intensity are used widely in speaking style, literary style, publisistic style and epistolary style. And in official style during commenting scientifical problems speaker can use intensity forming means in order to increase the influence of thought if its needed.

\section{References}

[1] Abdullayev N.Ә. The base of speech culture. Bak1: 2013, $277 \mathrm{p}$
[2] Adilov M.İ. Traces. 2 parts, II part.Bakı: Science and education, 2011, $370 \mathrm{p}$

[3] Adilov M.İ. Verdiyeva Z.N., Agayeva F.M. Explanatory linguistics terms. Bak1: Maarif, 1889, 364p

[4] Anar. Traces. 2parts, I part. Bakı: Nurlan, 2003, 606p

[5] Cabbarlı C.Q. Traces: 4 parts, I part, Bakı: East-West, $2005,328 \mathrm{p}$

[6] Gurbanov A.M. General linguistics. 2 parts, II part. Bak1: Maarif, 1993, 548p

[7] Mammadguluzadeh J.M. Traces. 3 parts, III part. Bakı: Azerbaijan SSRSA publication, 1967, 431p

[8] Mustafayev G.H. The style of Azerbaijan language. Text-book. Bak1: Science, 2010, 392p

[9] Orujov A.A. Explanatory dictionary of Azerbaijan language. 4 parts. I part. Bakı: East-West publication, 2006, 744p

[10] Russian- Azerbaijani dictionary (by editor A. Orujov) ANAS Lingustics İnstitute. 3parts, I part. Bak1: Onder publication, 2004, 328p

[11] Vahabzade B.M. Choosen Traces: 2parts, I part. Bak1: Onder publication, 2004, 328p

[12] Vagif M.P. Traces. Bak1: East-West. 2004, 264p

[13] Valiyeva S. It's snowing. "Odəbiyyat” newspaper. 28 may, № 20 (5039), 2016, 32p

[14] Valiyeva Sh. Twolegged. "Odəbiyyat" newspaper. 28 may 4 june № 21 (5040), 2016, 32p

\section{Author Profile}

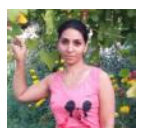

Khayala. M. Mursaliyeva is a Ph.D student of Azerbaijan language and Linguistes department of Sumgayit State University. She is studing on her doctoral work named "Grammatical expressing means of intensity in modern Azerbaijan language". Her specialization is Linguistics. She is working as Azerbaijan language teacher in Sumgait State University. 